\title{
REPORT OF THE WAR PREPAREDNESS COMMITTEE OF THE AMERICAN MATHEMATICAL SOCIETY AND MATHEMATICAL ASSOCIATION OF AMERICA AT THE CHICAGO MEETING
}

This report is concerned with three important questions: (1) The deferment of mathematicians; (2) Report of Subcommittee on Education for Service; (3) Use of Selectees.

\section{The Deferment of Mathematicians}

When this problem arose for the first time over a year ago the great majority of mathematicians were against seeking any special consideration of mathematicians in connection with the Selective Service. It is the feeling of many that the situation has now changed to such an extent that steps should now be taken leading to the "individual occupational deferment" of mathematicians.

We are concerned in the first place with teachers of mathematics in the colleges and universities, with advanced students of mathematics, and with mathematicians in industry. Mathematicians in the industries essential for the defense are fairly well taken care of in accordance with recommendations to the Selective Service Boards by their employers. But teachers of mathematics are variously treated by the Selective Service Boards. Some men are deferred because they are teaching mathematics to engineers, but this rule is not general. A state Selective Service official to whom the case of a mathematician was appealed, stated that the national authorities had certified no shortage of mathematicians.

Because of the Selective Service law each man must be treated on his own merits in accordance with the principles of "individual occupational deferment." It became apparent on consultation with Dr. Zook of the American Council on Education and others that the opinions of mathematicians must be given statistical support. A subcommittee of the War Preparedness Committee on the Supply and Demand for Mathematicians was accordingly appointed in June as follows: Professors T. Y. Thomas (chairman), Harry Bateman, E. T. Bell, G. C. Evans, and W. M. Whyburn. This committee has begun its investigations. It has sent a questionnaire to the heads of departments of mathematics. The committee is concerned with the number, relative quality, induction, and employment of mathematicians of the Selective Service age. It will give special attention to the needs of engineering schools and industry. 
If the results shown by this questionnaire warrant, a report should be made to General Hershey in charge of the Selective Service. Late last fall the American Council on Education issued a bulletin backed by General Hershey in which local Selective Service Boards were advised to give special consideration to men in chemistry, physics, engineering, biology, et cetera, with reference to the desirability of granting "individual occupational deferment." Mathematics was not listed. This bulletin was prepared with the aid of President Jewett of the National Academy.

This spring President Morse and Dean Richardson recommended to President Jewett that applied mathematics and, in particular, engineering mathematics be added to the fields listed in the bulletin of the American Council on Education.

In conclusion we may say that the opinion of mathematicians that there is a shortage or potential shortage of mathematicians will not affect the Selective Service policy unless backed by an established statistical position and a united front.

\section{Subcommittee on Education for Service}

An excellent report by this committee has been published in the American Mathematical Monthly. The earlier joint report with Morse was published in the Monthly and in the Mathematics Teacher. Copies were bought by the Government in some numbers. Considerable interest has been shown by various schools and teachers associations. The Hart report has reached a large number of college and university teachers of mathematics and some high school teachers. Nevertheless it is felt desirable that it also be brought to the attention of administrators of secondary schools. ${ }^{1}$

\section{ON the Use of Selectees}

A considerable number of young mathematicians write to Morse as Chairman of the War Preparedness Committee stating that they may be selected and asking for help. Some wish to be used outside the Selective Service, others merely to be used in the Selective Service in some way appropriate to their mathematical training.

Very little can be done to obtain employment for these men outside the Selective Service. However, in all cases a letter has been sent to the Adjutant General giving essential data concerning the selectee together with recommendations as to his use when he is especially well qualified. These letters are cordially received by the Adjutant Gen-

${ }_{1}^{1}$ The Council and Board of Governors subsequently voted to distribute the report to the list of 3500 superintendents of schools of the National Education Association. 
eral who has prescribed the general nature of the data desired. These data include a brief tabular vita, with age, degrees, positions, experience of mathematician and number and address of local Selective Service Board. Courses in engineering and experience with precision instruments are important. A number of the better trained young mathematicians have been placed in positions where their talents will be used to advantage.

\author{
Marston Morse, \\ Chairman, War Preparedness Committee
}

